\title{
DESIGN OF AN AUTOMATIC LIMB THERAPY REHABILITATION DEVICE
}

Benjamín Alejandro Rosas Revilla

Universidad Privada del Norte, (Peru). E-mail:n00138860@upn.pe ORCID: https://orcid.org/0000-0003-2672-574X

Ricardo Manolo Cruz Evangelista Universidad Privada del Norte, (Peru). E-mail: n00071527@upn.pe ORCID: https://orcid.org/0000-0002-7587-2546

Sebastian Sanchez Diaz

Universidad Privada del Norte, (Peru).

E-mail: sebastian.sanchez@upn.pe ORCID: https://orcid.org/0000-0002-0099-7694

Edward Flores Universidad Nacional Federico Villarreal Grupo de Investigación GISI - EUPG, (Peru). E-mail: eflores@unfv.edu.pe ORCID: https://orcid.org/0000-0001-8972-5494

\section{Citación sugerida:}

Rosas, B. A., Gruz, R. M., Sanchez, S., y Flores, E. (2022). Design of an automatic limb therapy rehabilitation device. 3C Tecnología. Glosas de innovación aplicadas a la pyme, Edición Especial, (febrero 2022), 113-135. https://doi.org/10.17993/3ctecno.2022.specialissue9.113-135 


\section{ABSTRACT}

The objective of this research work is to design an automatic rehabilitation device in charge of limb therapy in specialized rehabilitation centers. Within the methodology, the quantitative approach was followed, presenting a type of prospective research with a nonexperimental design, for this the design of the device was elaborated in its different stages, which were segmented into electronic design, Adaptive structure and Control interface. For this, different matrices were elaborated to obtain the most important characteristics of the adaptive design. In addition, torque and weight calculations were carried out so that the device can work in optimal conditions. It was concluded in the realization of the design of the control and programming system, the adaptive structure of the same device, the power and control circuits for the electronic part, all this making use of the engineering programs Autodesk Inventor, Proteus, Pic C Compiler. Likewise, the simulation was carried out to ensure the correct functioning of the device. Finally, a stress analysis was performed, obtaining a fairly high safety factor.

\section{KEYWORDS}

Mechatronics, Device, Systems, Rehabilitation, Physiotherapists. 


\section{INTRODUCTION}

At present there are various types of treatments for physical rehabilitation, each one of them has its benefits and harms, some authors made comparisons between Conventional Physiotherapy and Wiitherapy (Wibelinger et al., 2013), on the other hand, Vibrotherapy is applied (Rodríguez et al., 2006), and "Electro shock, electromagnetic waves, acupuncture, suction cups, among others" (Colegio profesional de Fisioterapeutas de Andalucía, 2012). On the mechatronic side, different equipment has been developed for the treatment such as a mechatronic rehabilitator for ankle sprain (Guzmán \& Matías, 2017).

All these devices focus on rehabilitation of tendons, joints, mobility aid, muscle relaxation aid. Therefore, "worldwide it is much easier to treat an injury or have more effective rehabilitation therapies" (Alburqueque \& Rondón, 2019; Araujo \& Chirinos, 2017; Cortés, Vergaray, \& Torrejón, 2017). "In the same way, in Peru several assistive devices in physiotherapy are also being developed, in many cases they are still in the preliminary or development phase" (Camacho, 2018). In the field of Rehabilitation, the most used is Conventional Therapy, aided by magnetic waves, TENS and suction cups.

By not having so much technological development applied in this area, "physiotherapists suffer from ergonomic risk, leading to injury" (Montoya, 2016). "In our country there is no applied technology to carry out therapies, this reduces productivity in treatments, due to the fact that several patients cannot be attended at the same time and it generates saturation in the attention, for this reason the specialized centers of integral rehabilitation are not alien to this problem, many of the physiotherapists suffer injuries in upper extremities, backs produced by the ergonomic risk and work stress generated in their work routine" (Montoya, 2016; Leyva et al., 2011; Morales \& Goiriz, 2020). In the following graph the authors Carrera and Morales (2020) shows us the most frequent injuries in physiotherapists. 


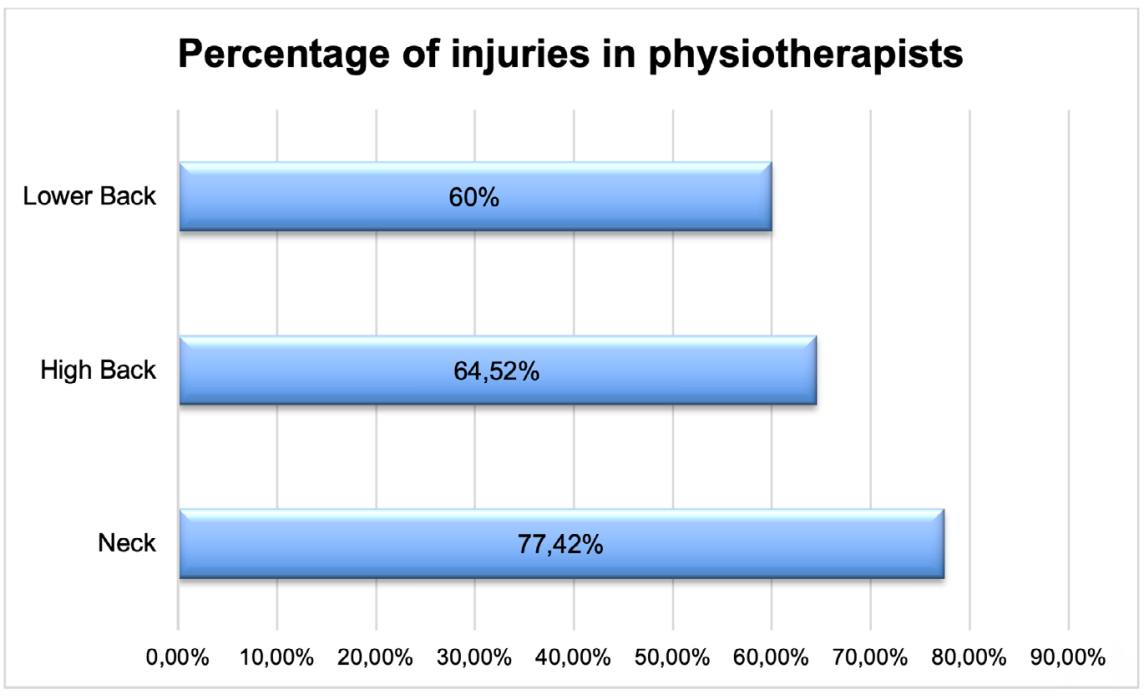

Note: Results obtained from Evaluación del riesgo ergonómico por posturas forzadas en el área de fisioterapia del Hospital de Especialidades Carlos Andrade Marín.

Figure 1. Frequent injuries in physiotherapists in their work routine.

Source: (Carrera \& Morales, 2020).

The objective of this project is to design a device that allows limb muscles to be relaxed for patients undergoing physical rehabilitation thanks to the fact that our design allows the device to carry out the therapies in an automated and personalized way for each patient. In addition, it provides the ability to perform therapies in parallel to alleviate the high demand for patients. To achieve compliance with the proposed objectives, a non-invasive or harmful prototype for the patient will be designed to establish corrective observations in favor of health. Its result will allow finding alternative solutions according to the needs of patients and Physiotherapists.

\section{MATERIALS AND METHODS}

As objectives of our Project, we have the following:

- Design an adaptable structure for various muscles and limb sizes of rehabilitation patients.

- The hardware and software must be interactive and user-friendly with the user and/or physiotherapist.

- Electronic design segmented into different stages, both analog and digital. 
To comply with the aforementioned, we propose a flow chart in which we determine the operating process of this device, in this way we can identify the factors that influence when performing a decontraction therapy.

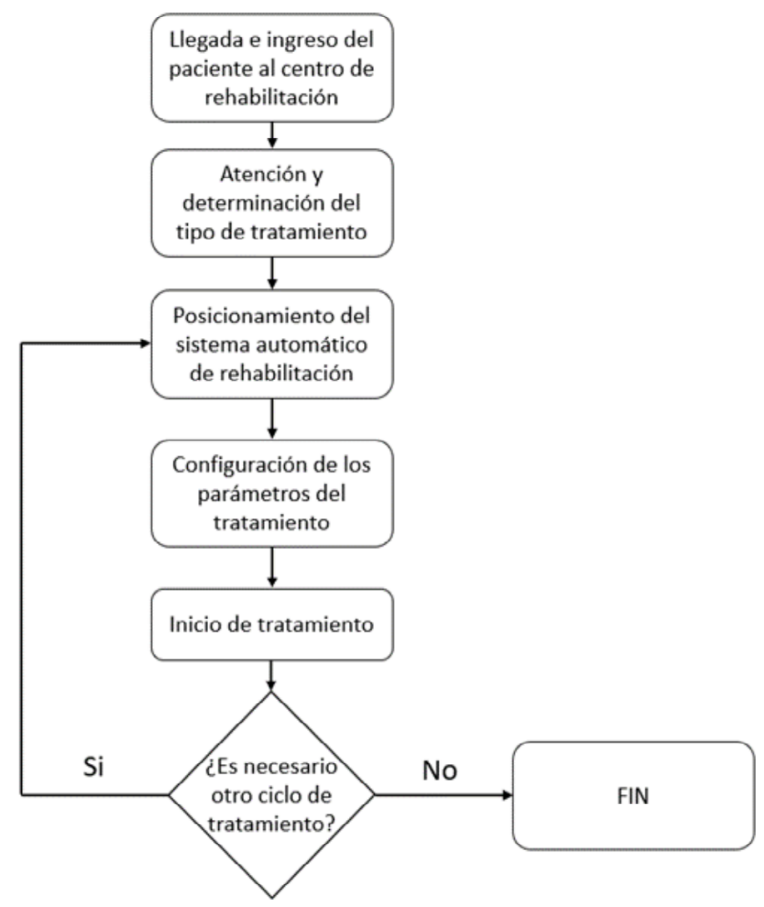

Figure 2. Flowchart proposed of the processes when performing a decontraction therapy.

Source: own elaboration.

For the design of the automatic rehabilitation device, the black box diagram specified in Figure 3, where the inputs of the system are taken into consideration in order to obtain an automated and personalized therapy for each patient.

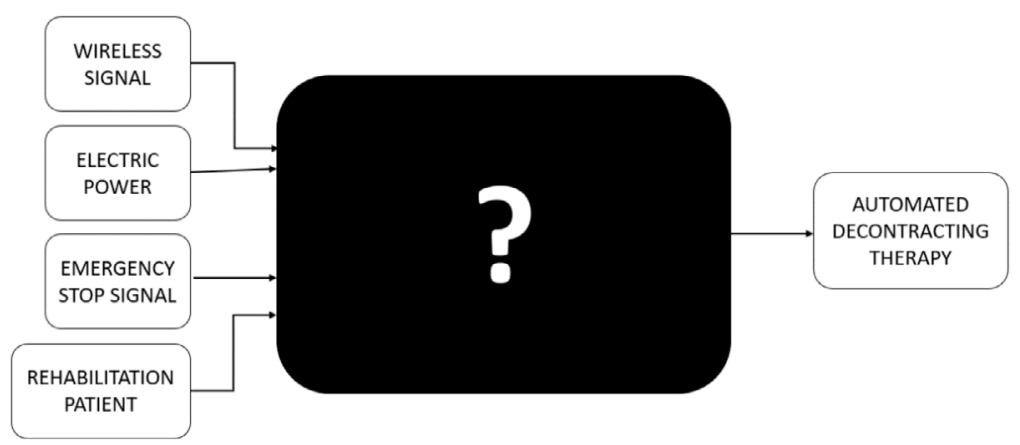

Figure 3. Black box diagram of the device needs.

Source: own elaboration. 
After making the black box diagram, the functions that it will perform for the operation of the device were specified. As a result, the function diagram Figure 4 in which the subsystems that belong to the control stage are determined considering the inputs mentioned above and the output to be obtained.

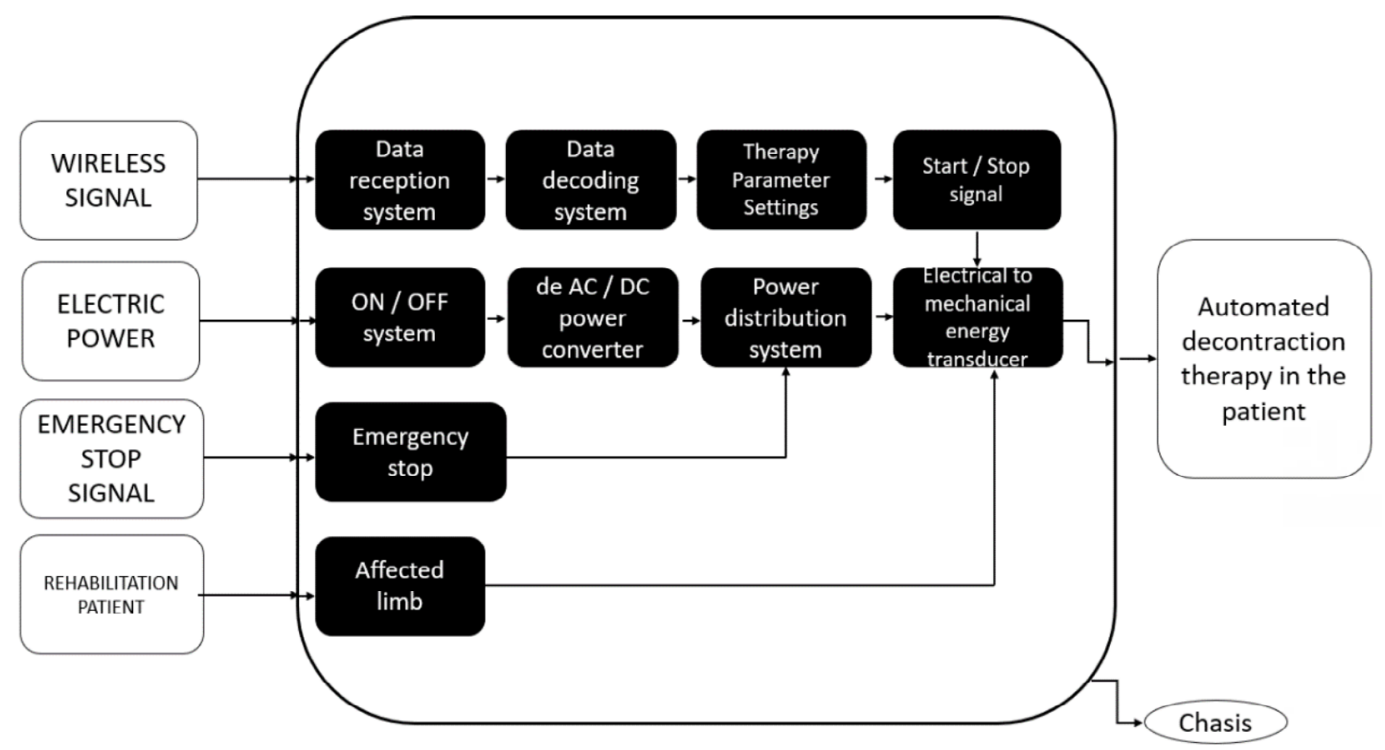

Figure 4. Function diagram of the device design.

Source: own elaboration.

To carry out the design of all the hardware and software we take into account certain criteria determined by the needs of the physiotherapist for their correct use in rehabilitation. This was done using the pair comparison matrix (Figure 5) with the following criteria:

- Impact resistence.

- Adaptability of the device.

- Manufacturing material.

- Ease of manufacture.

- Easy use of the physiotherapist.

- Maintenance.

- Aesthetic. 


\begin{tabular}{|c|c|c|c|c|c|c|c|c|c|}
\hline & 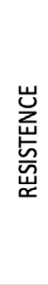 & 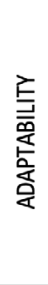 & 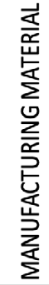 & 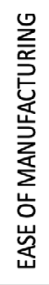 & 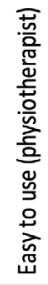 & 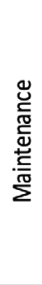 & 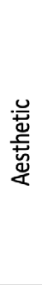 & $\begin{array}{l}\bar{\Xi} \\
\bar{\xi} \\
\bar{n}\end{array}$ & 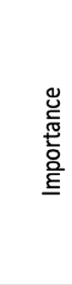 \\
\hline IMPACT RESISTENCE & & $\mathbf{0}$ & 1 & 1 & 0 & 1 & 1 & 4 & 1.905 \\
\hline ADAPTABILITY & 1 & & 1 & o & 1 & 1 & 1 & 5 & 2.381 \\
\hline $\begin{array}{l}\text { MANUFACTURING } \\
\text { MATERIAL }\end{array}$ & $\mathbf{0}$ & $\mathbf{0}$ & & $\mathbf{0}$ & 1 & 1 & $\mathbf{0}$ & 2 & \\
\hline $\begin{array}{l}\text { EASE OF } \\
\text { MANUFACTURING }\end{array}$ & $\mathbf{0}$ & 1 & 1 & 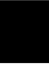 & 1 & 1 & $\mathbf{0}$ & 4 & 1.905 \\
\hline $\begin{array}{l}\text { Easy to use } \\
\text { (physiotherapist) }\end{array}$ & 1 & o & o & $\mathbf{0}$ & & 1 & 1 & 3 & 1.429 \\
\hline Maintenance & 0 & $\mathbf{0}$ & $\mathbf{0}$ & $\mathbf{0}$ & $\mathbf{0}$ & & 1 & 1 & 0.476 \\
\hline Aesthetic & $\mathbf{0}$ & o & 1 & 1 & o & 0 & & 2 & 0.952 \\
\hline
\end{tabular}

Figure 5. Pair comparison matrix for optimal device design.

Source: own elaboration.

By doing this analysis for the design criteria, we were able to get the most important points to take into account when designing the entire rehabilitator. As a result, we had that the device must present a structure adaptable to the different extremities of each patient to be treated in the specialized center. At the same time, the criteria of resistance to impact and ease of manufacture are equally important. In addition, the easy use of it occupies the third place on this list since it is a very necessary point for the development of this design. Finally, it was determined that aesthetics, maintenance and manufacturing material are the criteria with the lowest value obtained in the table, but they are still important within the needs of the device.

\subsection{CONTROL INTERFACE}

We elaborated the control interface design in the MIT App Inventor software "due to its possibility of creating applications for IOS and Android in a simple way with bluetooth communication, which is the communication protocol used in our rehabilitation device" (Gutsens, 2020; Ven, 2017).

For the design of the application, we took into account the following parameters to enter, in the same way it is shown in the block diagram of Figure 6. 
- The Bluetooth connection with the automatic rehabilitation device.

- The therapy time established by the physiotherapist.

- The intensity of the therapy regulated by the effector.

- The position of the effector on the $\mathrm{X}$ axis depending on the type of muscle.

- The therapy start signal.

- An emergency stop controlled from the app.

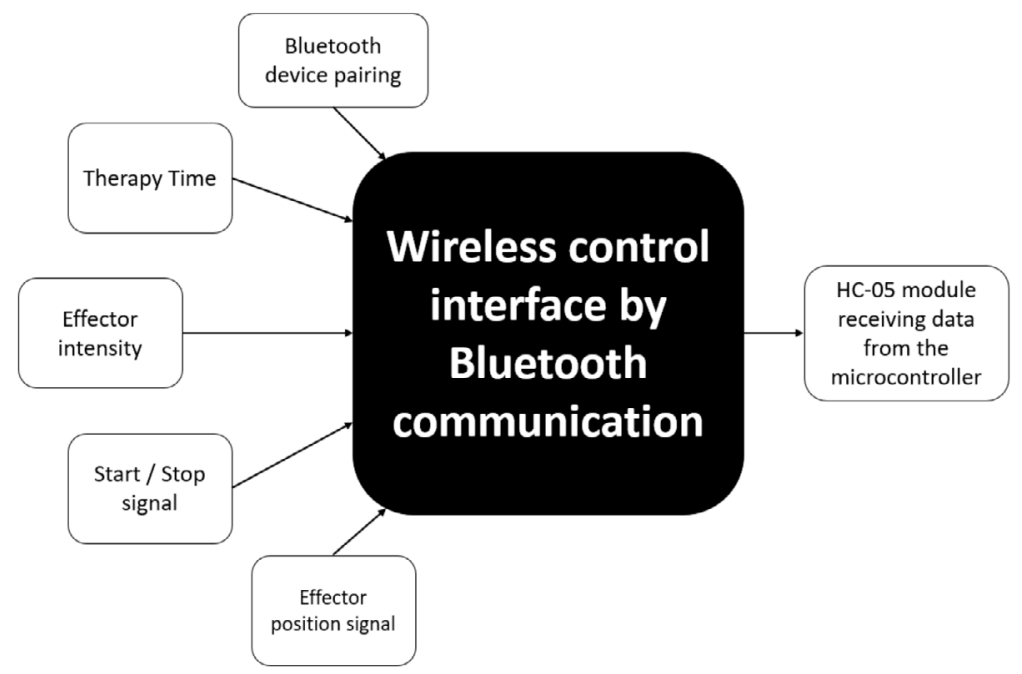

Figure 6. Block diagram of the device's bluetooth user control interface.

Source: own elaboration.

\subsection{PROGRAMMING}

In the programming design stage, we define two stages, "the first is the data reception stage commissioned by the 16F628A microcontroller and the second stage which controls the actuators and receives the data from the sensors for the correct operation of the device" (Delgado, 2020), "this last stage is designed for the 16F877 microcontroller" (E-Marmolejo, 2017).

The block diagram followed to carry out the programming is shown in Figure 7. 


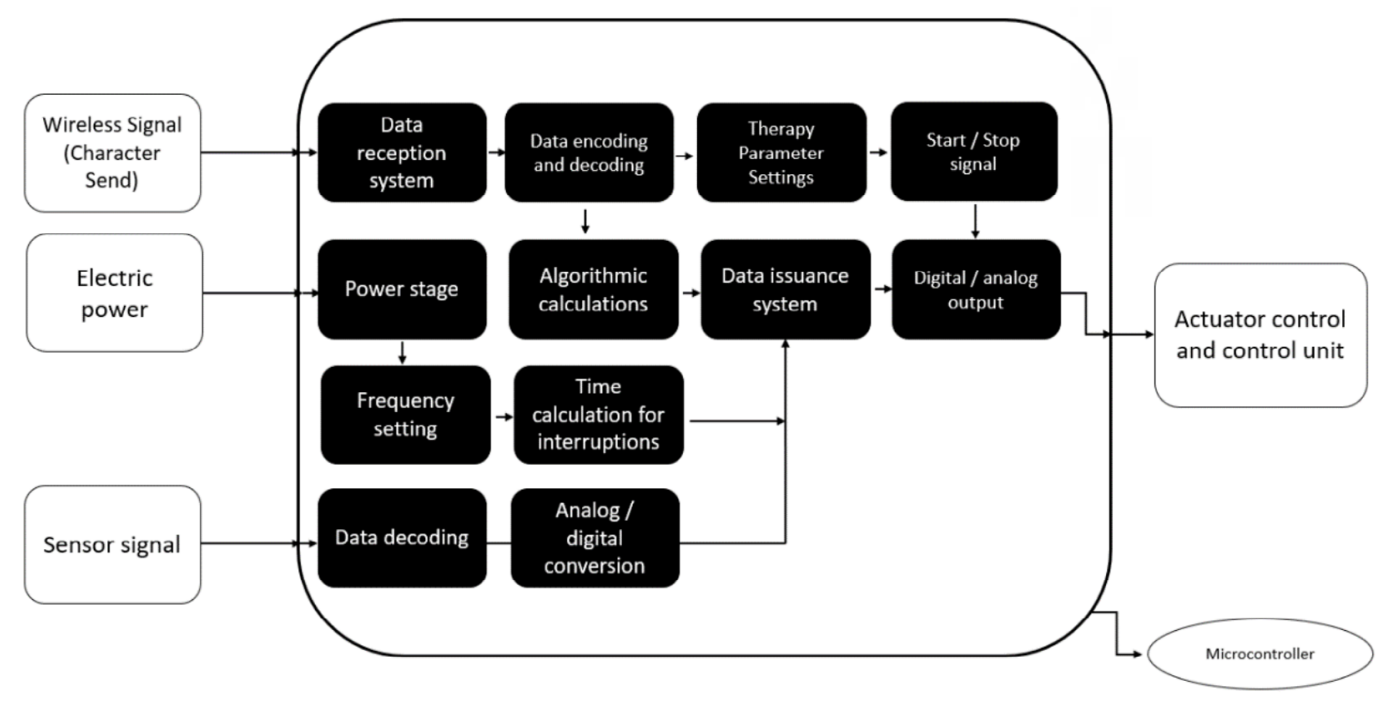

Figure 7. Block diagram of the microcontroller functions for actuator control and therapy customization. Source: own elaboration.

As mentioned above, the programming of the first microcontroller will be focused on the time management established by the physiotherapists and all the additional configurations for the customization of each therapy, for this, the data is received from the bluetooth interface, for this particular case all they will be characters, then, depending on whether they are data of time, intensity, movement, etc. It will load the necessary value into the microcontroller and then execute the start order to the other microcontroller in charge of actuator control. This is seen in the following figure (Figure 8). 


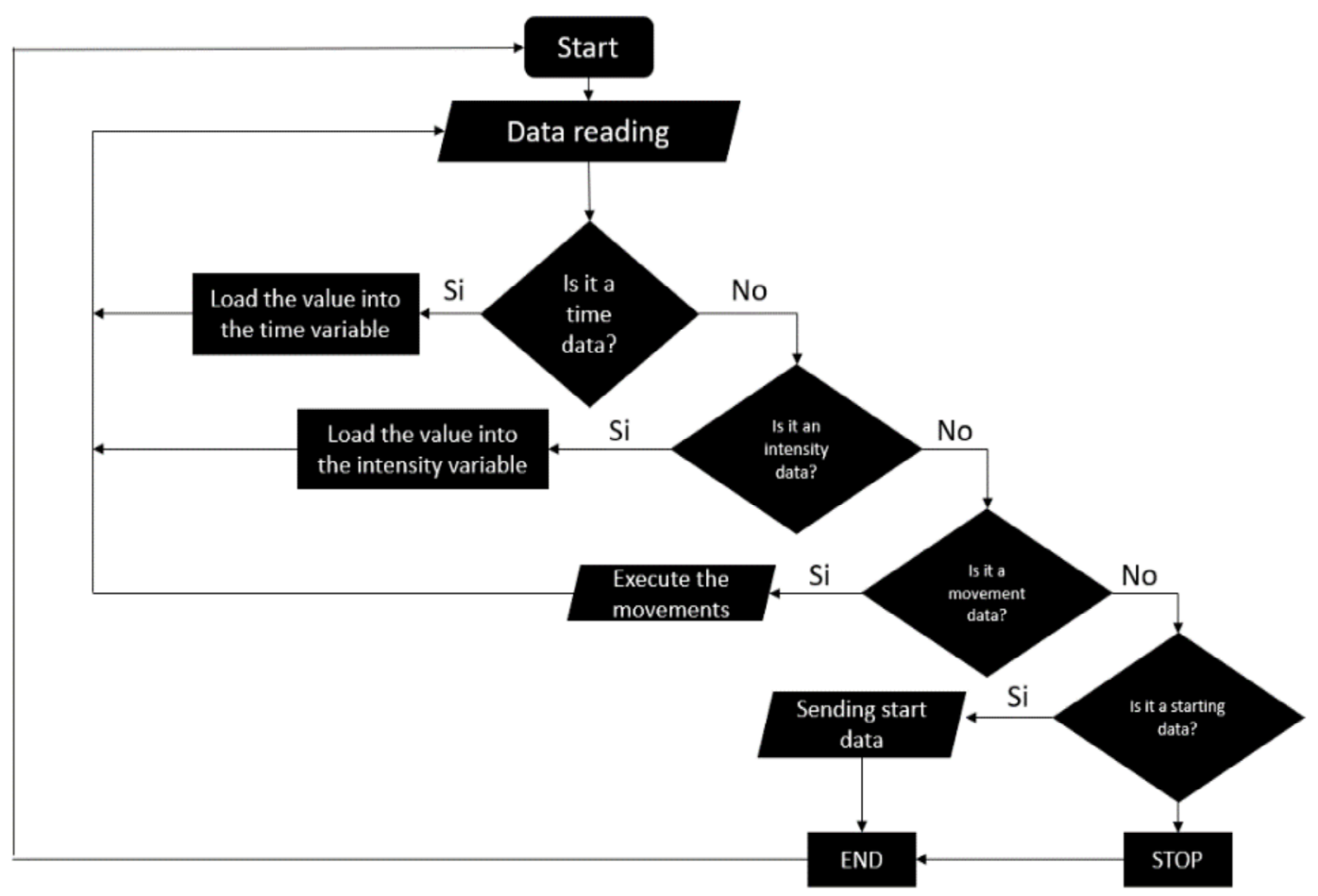

Figure 8. Flow diagram of the logic to follow for the elaboration of the code.

Source: own elaboration.

After elaborating the logic, we proceeded to write the programming code, which carries interruptions of the timer 0 located inside the microcontroller to count the time.

The second microcontroller is focused on receiving data from the sensor, stepper motor control (PAP) through A4988 modules and DC motor control through Pulse Width Modulation (PWM). Because this microcontroller will always be in operation, it will be disabled, until it receives the start data from microcontroller 1 where it can finally perform the analysis of the sensors in IF conditionals and then execute one action or another. The logic for the elaboration of this code is seen in the following flow diagram (Figure 9). 


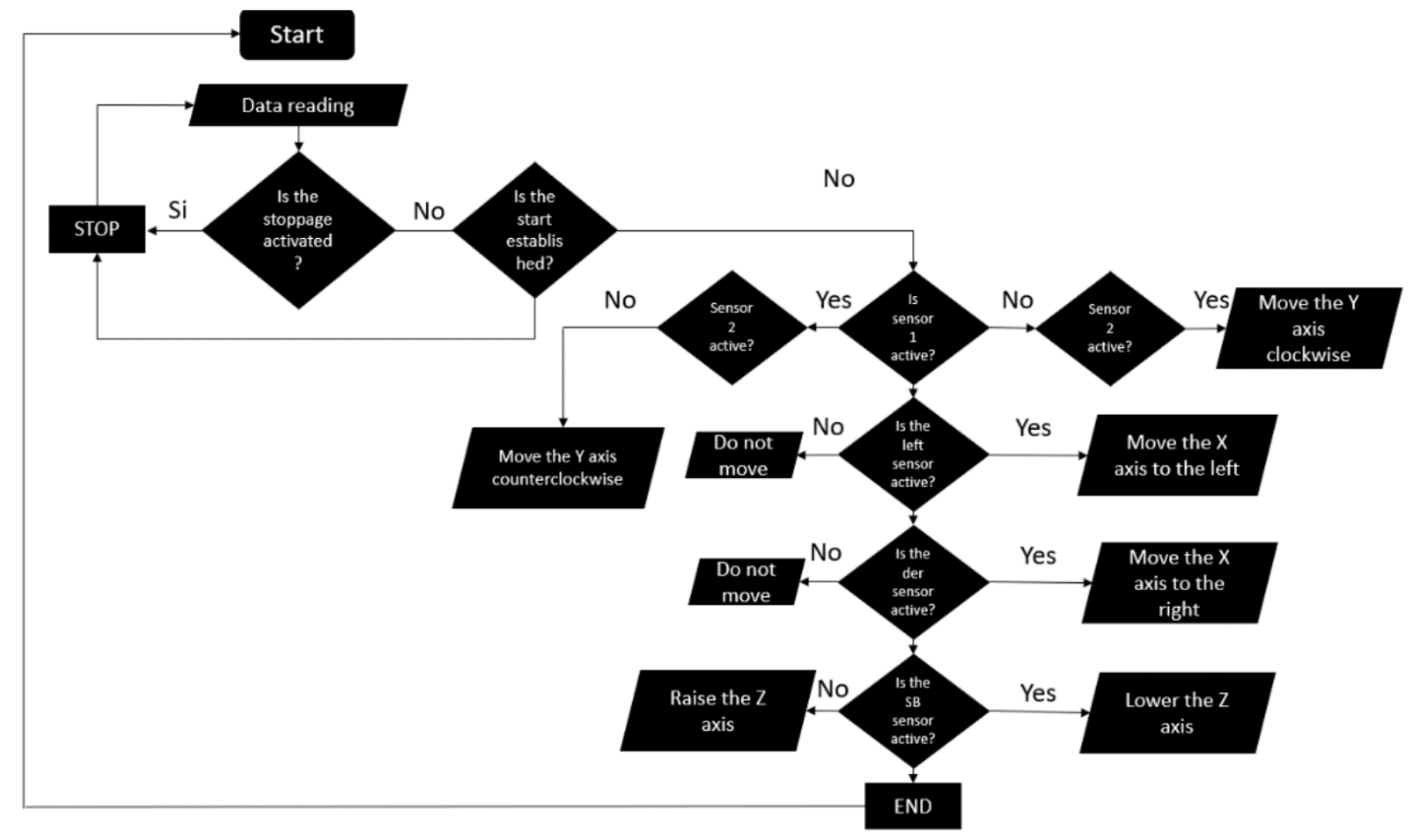

Figure 9. Flow diagram of the microcontroller in charge of the power stage and sensor reading.

Source: own elaboration.

With the defined diagram, we proceeded to read the data from the sensors and with them define whether the motor was moving in one direction or another, in addition, we made use of timer 2 and its interruptions of the microcontroller to control the PWM of the DC motor.

\subsection{STRUCTURE}

Information was collected by analyzing the work area of the physiotherapists taking into account how the therapies are carried out in the extremities, with this, several design ideas and corresponding measures of the structure were raised to perform the therapies, once this was obtained, the 3D design in Autodesk Inventor software with appropriate measurements. The first design proposed for the device is seen in the following figure. 


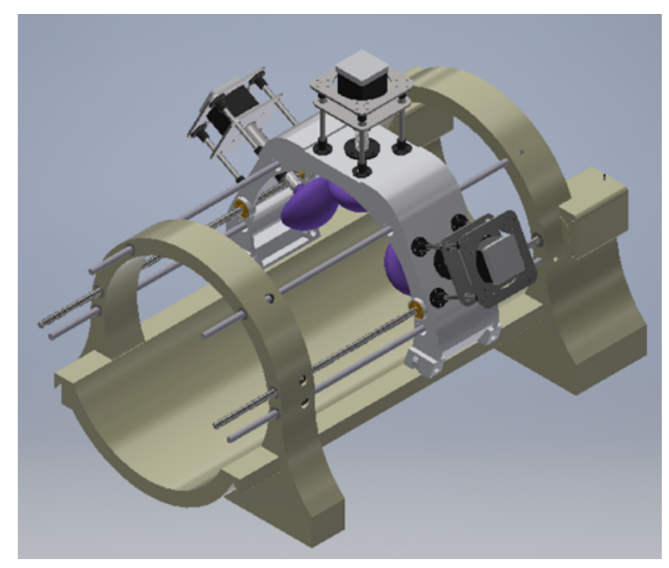

Figure 10. First structural design of the rehabilitation device.

Source: own elaboration.

With the designed structure, we proceeded to calculate the necessary torque of the motors to carry out the movement of the "X", "Y" and "Z" axes. To begin, we collect the mass data that the inventor software offers us, obtaining the following results shown in the following table.

Table 1. Torque calculation as a function of mass and its type of movement.

\begin{tabular}{|c|c|c|}
\hline KIND OF MOVEMENT & MASS & TORQUE \\
\hline Axis $Y$ & $3.4 \mathrm{Kg}$ & $2.677 \mathrm{Kgf.cm}$ \\
\hline Axis $X$ & $1.87 \mathrm{Kg}$ & $0.887 \mathrm{Kgf.cm}$ \\
\hline Axis $Z$ & $1.1 \mathrm{Kg}$ & $0.514 \mathrm{Kgf} . \mathrm{cm}$ \\
\hline
\end{tabular}

Source: own elaboration.

With the calculation of the torque of the motors we make the necessary selection of them, for each of them we determine as a quality criterion the use of PAP motors, since they offer more precision when executing their movement, and for use in rehabilitation is an important criterion for design. We prepare a table shown in Table 2 with the specifications of the stepper motors to be used, and with this we make the selection according to their optimal torque and needs.

Table 2. PAP motors and their various characteristics to meet design criteria and proper selection.

\begin{tabular}{|c|c|c|c|c|c|c|c|c|c|c|}
\hline Motor & $\begin{array}{l}\text { Voltage } \\
\text { (V) }\end{array}$ & $\begin{array}{c}\text { Current } \\
\text { (A) }\end{array}$ & $\begin{array}{c}\text { Par } \\
\mathrm{kg}^{*} \mathrm{~cm}\end{array}$ & $\begin{array}{l}\text { Inertia } \\
\mathbf{g}^{*} \mathrm{~cm}^{2}\end{array}$ & $\begin{array}{l}\text { Length } \\
(\mathrm{mm})\end{array}$ & $\begin{array}{c}\mathrm{N} \# \text { of } \\
\text { conections }\end{array}$ & $\begin{array}{c}\text { Temp } \\
\text { min }\end{array}$ & $\begin{array}{c}\text { Temp } \\
\max \end{array}$ & $\begin{array}{c}\text { Step } \\
\text { Angle }\end{array}$ & $\begin{array}{c}\text { Weight } \\
\mathrm{Kg}\end{array}$ \\
\hline $\begin{array}{c}\text { NEMA } 8 \\
\text { SY20STH42- } \\
\text { 0804A }\end{array}$ & 4.32 & 0.8 & 0.33 & 3.6 & 42 & 4 & -20 & 50 & 1.8 & 0.08 \\
\hline
\end{tabular}




\begin{tabular}{|c|c|c|c|c|c|c|c|c|c|c|}
\hline $\begin{array}{c}\text { NEMA } 11 \\
\text { SY28STH32- } \\
\text { 0956A }\end{array}$ & 2.66 & 0.95 & 0.43 & 9 & 31 & 6 & -20 & 50 & 1.8 & 0.12 \\
\hline $\begin{array}{c}\text { NEMA } 17 \\
\text { SY42STH33- } \\
\text { 1334A }\end{array}$ & 2.8 & 1.68 & 3.6 & 54 & 38 & 4 & -20 & 50 & 1.8 & 0.285 \\
\hline $\begin{array}{c}\text { NEMA } 23 \\
\text { SY57STH76- } \\
2804 A\end{array}$ & 3.2 & 2.8 & 18.9 & 480 & 76 & 4 & -20 & 50 & 1.8 & 1.03 \\
\hline $\begin{array}{c}\text { NEMA } 34 \\
\text { SY85STH156- } \\
\text { 4208A }\end{array}$ & 5.25 & 4.2 & 122 & 4000 & 156 & 8 & -20 & 50 & 1.8 & 5.35 \\
\hline
\end{tabular}

Source: own elaboration.

With the selection criteria carried out, we obtained that the engines to be used will be the following:

- PAP Nema 14 motor for "X" movement.

- PAP Nema 17 motor for "Y" movement.

- PAP Nema 14 motor for "Z" movement.

Having the structure in the software, we proceeded to carry out the "analysis and simulation tests that allow us to ensure its correct operation" (Torres, Camarillo, \& Orozco, 2013).

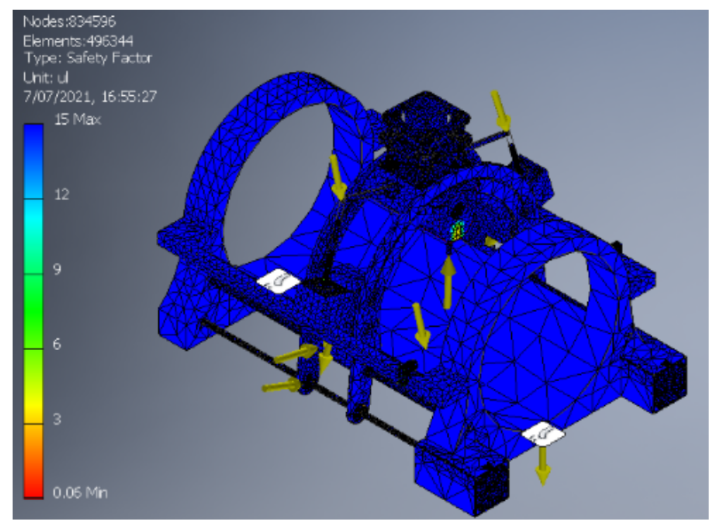

Figure 11. Stress analysis of the structure to obtain the safety factor and determine the safety of the device.

Source: own elaboration.

As can be seen in the graph, the safety coefficient is quite high, which ensures optimal support so as not to put the patient or the physiotherapist at risk with a structural failure. In addition, the design also has an adaptability depending on the lengths of each muscle. 


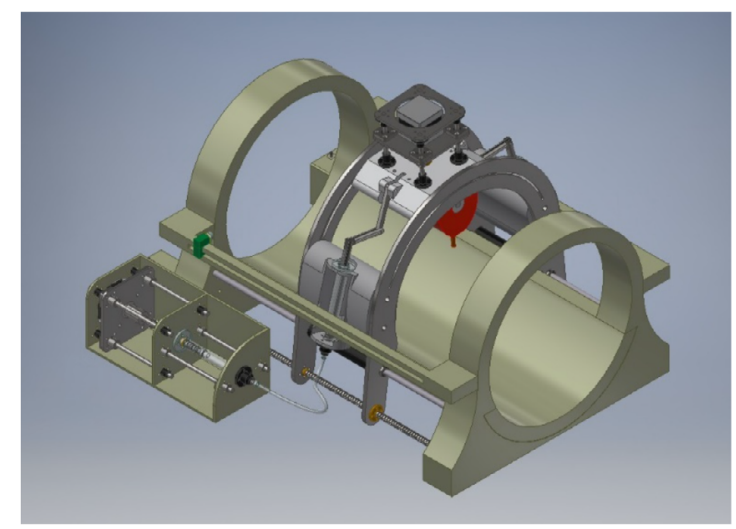

Figure 12. Final structural design of the automatic rehabilitation device.

Source: own elaboration.

This was achieved by implementing a pair of mobile sensors on the sides and millimeter rails so that the personnel in charge of therapy can regulate it depending on the therapy area.

With all the analysis carried out in the structural part, we made the corrections and obtained a final design of the automatic rehabilitation device which is shown in the following figure.

\subsection{ELECTRONICS}

We contemplate the needs of the equipment previously established as sensor inputs, and microprocessors, this helped us to carry out the data collection in parallel, in this way we could define the inputs, outputs and power stages of the system for the software stage and the electronic development in Proteus software 8.12 (Hubor-Proteus, 2015).

To obtain an electronic design we begin to order and classify it in stages, the power stage (actuators) would be the most important and an order and manufacturer specifications must be obtained to avoid temperature problems and short circuit.

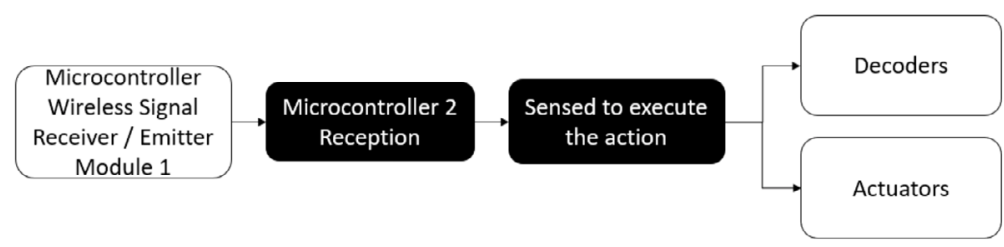

Figure 13. Classification of stages.

Source: own elaboration. 
We collect information on the connections of electronic devices that your data sheet offers us from each manufacturer.

We take as a reference these connections from a PIC16F88X family microcontroller with similar characteristics, in this case we will use the internal oscillator configuration and an external source that will power the entire control stage. and the recommended connections of a PIC16F887 microcontroller, in this case we will use the internal oscillator configuration and an external source that will power the entire control stage. For the power supply of the microcontrollers, we use a circuit based on the LM2596 DC-DC module. 7-segment displays are devices used to display information. On this occasion we can display digits from 0 to 9 . We use a 7447 decoder; it is an integrated circuit that converts the input binary code in BCD format to logic levels that allow activating a 7-segment common anode display where the position of each bar forms the decoded number. For the design of a PWM module we use an IRFZ44N transistor of MOS-FET technology.

Table 3. Driver selection for stepper motors.

\begin{tabular}{|c|c|c|c|}
\hline CONTROLLER & VOLTAGE (V) & OUTPUT CURRENT (A) & MICRO STEPS \\
\hline Driver TB 6600 & 20 a 42 & 0.2 a 5 & $1,1 / 2,1 / 4,1 / 8,1 / 16$ \\
\hline Driver TB6560 & 12 a 36 & 0.5 a 3.5 & $1,1 / 2,1 / 4,1 / 8,1 / 16$ \\
\hline Driver Pap A4988 & 8 a 35 & 1 a 2 & $1,1 / 2,1 / 4,1 / 8,1 / 16$ \\
\hline CNC shield & 12 a 36 & 1 a 2 & $1,1 / 2,1 / 4,1 / 8,1 / 16,1 / 32$ \\
\hline
\end{tabular}

Source: own elaboration.

This time we use the Driver PAP A4988 module because its technical specifications are adequate for the correct operation of the motors. Specifically, "this stepper motor controller allows you to control a bipolar stepper motor with an output current of up to 2 A per coil" (García, 2020).

\section{RESULTS}

As a first result, we obtained the final design of the user-friendly interface for the physiotherapist, which is shown in Figures 14 and 15. 


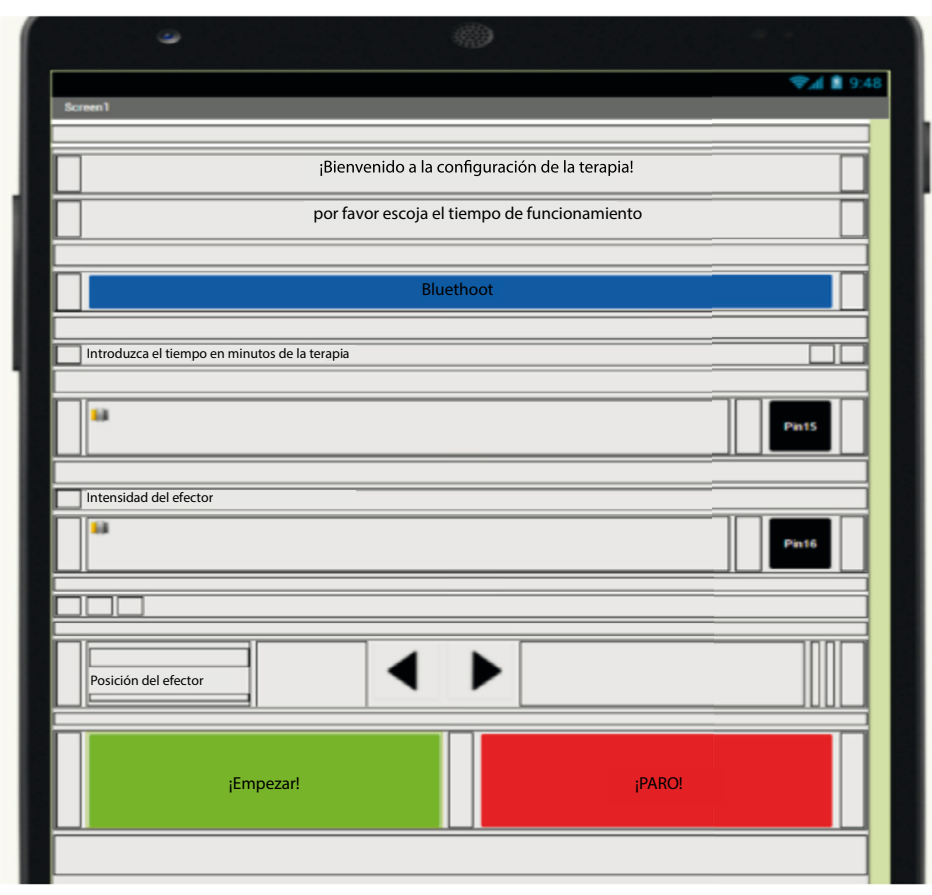

Figure 14. Final design of the interface seen from the MIT APP Inventor program. Source: own elaboration.

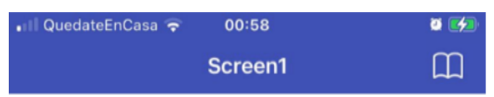

¡Bienvenido a la configuración de la terapia! por favor escoja el tiempo de funcionamiento.

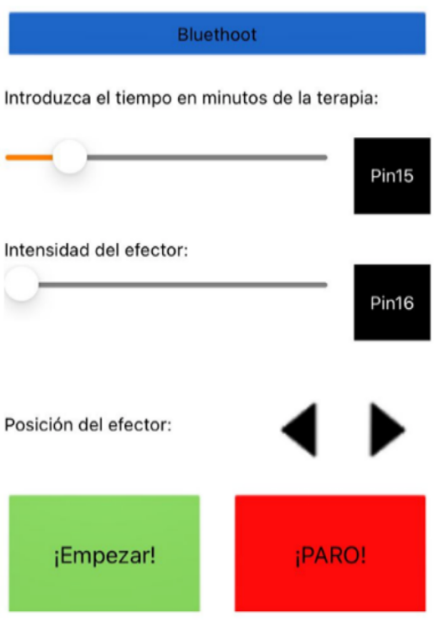

Figure 15. User interface application seen from an IOS device.

Source: own elaboration. 
When good results were obtained from the components that match the manufacturer's specifications, the plan for each electronic card was designed separately, specifying the inputs and outputs. $5 \mathrm{~V}$ is considered for digital circuits.

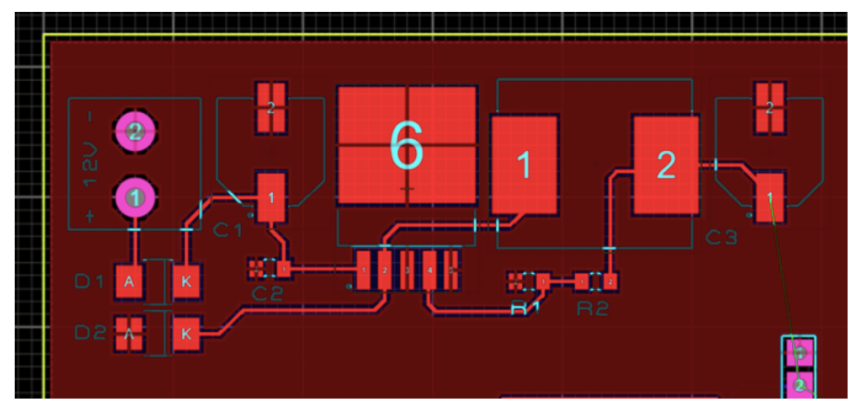

Figure 16. Design of the supply stage based on the LM2596 DC-DC module.

Source: own elaboration.

Additionally, a PWM module was designed for the effector. Next, the PCB board is designed, the measurements of the different stages were taken into account, track size according to the manufacturer, current, voltage.

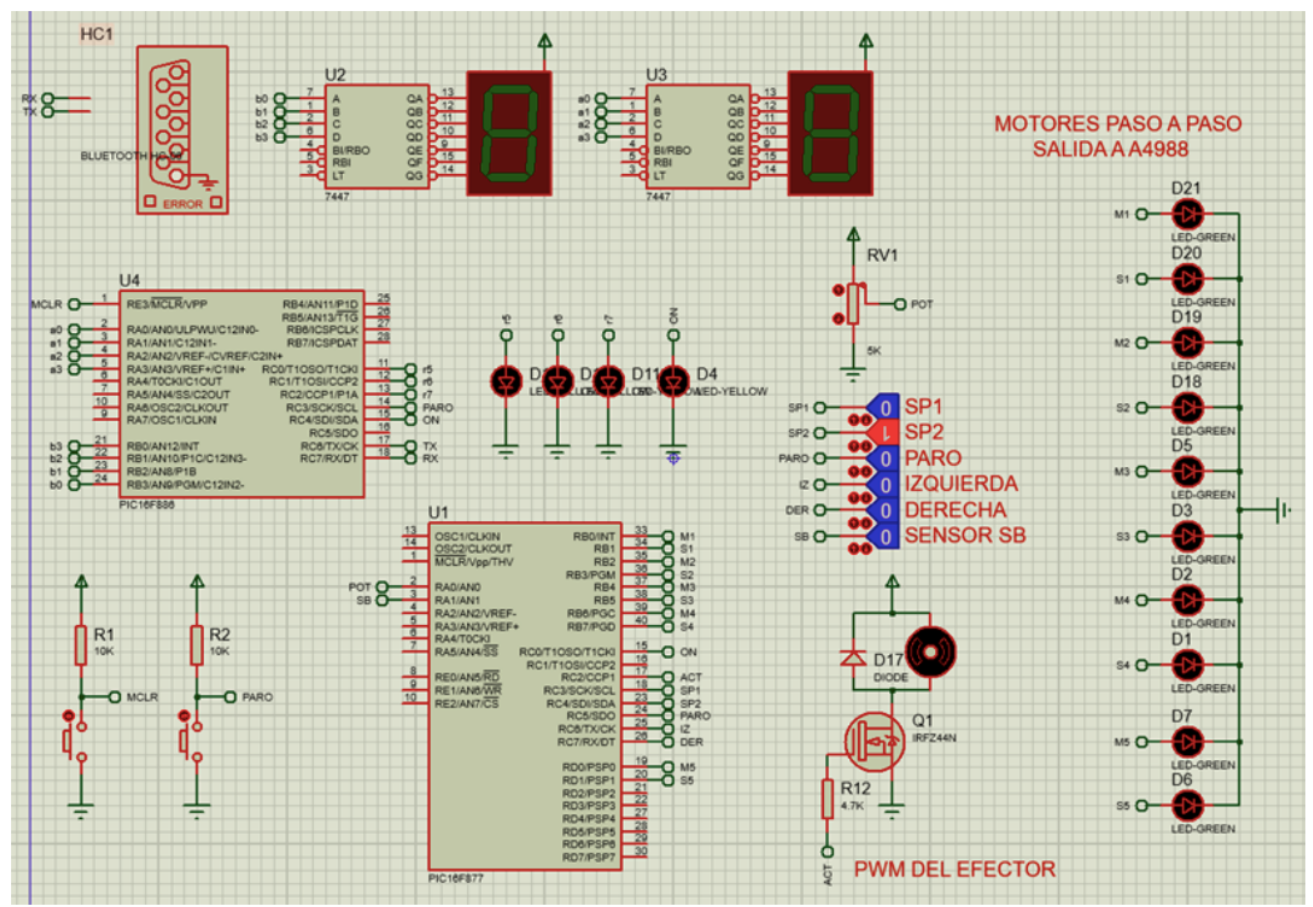

Figure 17. General schematic diagram of the electronic subsystem.

Source: own elaboration. 
A 3D design was obtained through the 3D visualizer option offered by the Proteus 8.12 software, which helped us in the implementation of a final design of the entire system.

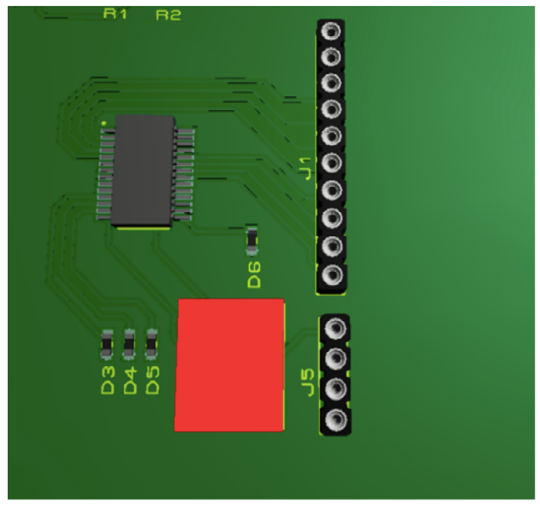

Figure 18. Design of Control 3D PCB in Proteus 8.12.

Source: own elaboration.

The main problems that arose, not having a consideration in the tolerances of the components and not isolating some stages that generated static current. An adjustment had to be made by modifying the size of the tracks and the order of some components for functionality and aesthetics. Additionally, some 3D components had to be designed in the Inventor software, since the Proteus software does not have all the necessary libraries.

Regarding the development of time programming and microcontrollers to personalize the therapy of patients, the corresponding tests were carried out on the oscilloscope of the Proteus 8.12 program and a wave of approximately 1 second was obtained as a result, with which it is performed the programming of the variable time of the therapy.

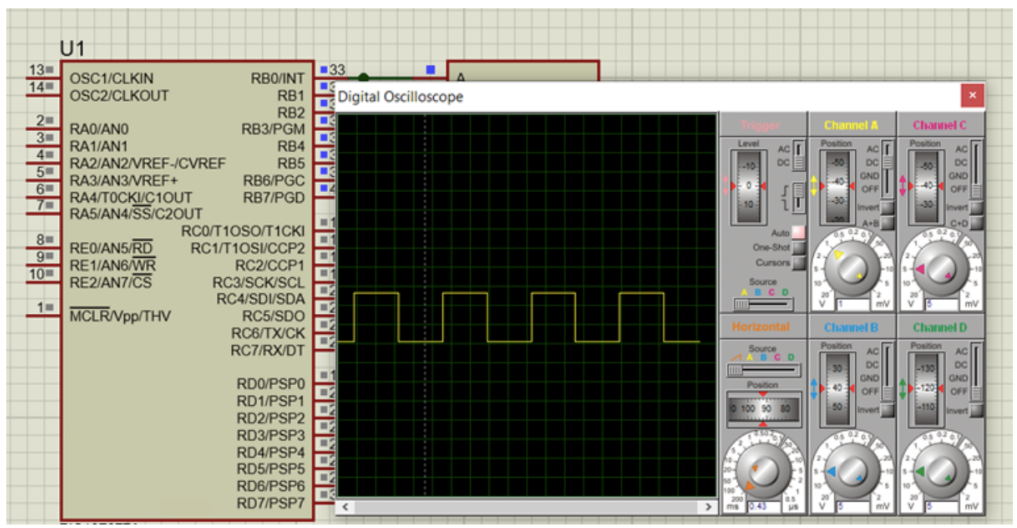

Figure 19. Calculation of the estimated time using the oscilloscope.

Source: own elaboration. 


\section{CONCLUSIONS}

An automatic rehabilitation device in charge of limb therapy was designed, it was possible in all its parts that make it up, obtaining the ability to execute parallel therapies and configuration through the mobile phone.

The design of the control stage was carried out in two parts, first the control interface for mobile phones in the MIT APP INVENTOR software where all the necessary parameters for rehabilitation therapy can be configured, in addition, the programming of the system of control based on two microcontrollers, one for receiving Bluetooth data and the other for controlling the device's power stage, thereby ensuring the optimal functioning of these subsystems.

The design of the PCB boards was carried out in different sections of control, power, feeding and decoding. This was achieved by using the Proteus 8.9 software where the schematic diagram of the circuit was made and then the PCB design with the respective simulation tests where we can check the correct operation of the electronic system.

The structural design was developed complying with all the requirements established by the physiotherapists, which should be adaptable and cover different work areas in the extremities, for this the design was elaborated in the Autodesk Inventor software, in addition, the parameters were studied of the mass and in this way the necessary calculations were carried out for the touches of the motors, which are: $2.677 \mathrm{Kgf.cm}, 0.887 \mathrm{Kgf.cm}$ and $0.514 \mathrm{Kgf.cm}$. The tension analysis was also carried out in the same software to obtain the safety coefficient that ensures the correct functioning of the device.

\section{REFERENCES}

Alburqueque, G., \& Rondón, L. (2019). Diseño e implementación de un exoesqueleto para fisioterapia en pacientes con artrosis de rodilla en la clinica geriátrica militar de Chorrillos [Tesis de Pregrado]. Universidad Ricardo Palma. http://repositorio.urp.edu.pe/handle/ URP/2697.

Araujo, B., \& Chirinos, A. (2017, November 13). Prototipo de sistema de complementación para la rehabilitación motriz de la mano derecha de las personas con artritis reumatoide [Tesis 
de Pregrado]. Universidad Peruana de Ciencias Aplicadas. http://hdl.handle. net/10757/622456.

Camacho, M. (2018). Diseño de una prótesis biomédica del miembro superior para mejorar el desempeño de actividades cotidianas en jóvenes utilizando materiales accesibles Lima - 2018 [Tesis de Pregrado]. Universidad Privada del Norte. https://repositorio.upn.edu. pe/handle/11537/21140.

Carrera, E., \& Morales, X. (2020). Evaluación del riesgo ergonómico por posturas forzadas en el área de fisioterapia del Hospital de Especialidades Carlos Andrade Marín [Tesis de Maestría]. Universidad Internacional SEK. https://repositorio.uisek.edu.ec/ handle/123456789/4156.

Colegio profesional de Fisioterapeutas de Andalucía. (2012). Guia de actos fisioterapicos vibroterapia como nueva terapia.

Cortés, T., Vergaray, B., \& Torrejón, J. (2017). Desarrollo de interfaz gráfica con sistema embebido para prototipo de rehabilitación pasiva de brazo. In Proceedings of the 15th LACCEI International Multi-Conference for Engineering, Education and Technology. https://doi.org/10.18687/LACCEI2017.1.1.179

Delgado, H. (2020, November 2021). Lenguaje de Programacion C. Akus Web. https:// disenowebakus.net/lenguaje-c.php

E-Marmolejo, R. (2017). Microcontrolador - qué es y para que sirve. HetPro. https:/ / hetprostore.com/TUTORIALES/microcontrolador/

García, V. (2020, March 5). "Descripción del driver A4988”. diarioelectronicohoy. https:// www.diarioelectronicohoy.com/blog/descripcion-del-driver-a4988

Gutsens, E. (2020, March 27). Cree su propia aplicación en Mit App Inventor. TecnoLIKE. https://tecnolikeplus.com/utilidades / cree-su-propia-aplicacion-con-mit-appinventor/. 
Guzmán, R., \& Matías, L. (2017). Diseño de un rehabilitador mecatronico para esguince de tobillo [Tesis de Pregrado]. Universidad Nacional Autónoma de México. https://ru.dgb. unam.mx/handle/DGB_UNAM/TES01000765112.

Hubor-Proteus. (2015). La Suite Proteus, Labcenter y Hubor. hubor. https://www.huborproteus.com/proteus-pcb/proteus-pcb/2-proteus.html

Leyva, B., Martínez, J. L., Meza, J. A., Martínez, A., \& Cernaqué, G. O. (2011). Riesgo ergonómico laboral en fisioterapeutas de un centro de rehabilitación física. Revista Medica Herediana, 22(1). https: / / doi.org/10.20453/rmh.v22i1.1100

Montoya, I. (2016, June 17). Análisis de las lesiones muscoesqueléticas en los fisioterapeutas de dos servicios de rehabilitación hospitalarios de la región de Murcia [Tesis de Maestría] Universidad Miguel Hernández de Alicante. http: / / 193.147.134.18/bitstream/11000/3340/1/ Montoya $\% 20$ Navarro $\% 2 \mathrm{C} \% 20$ Irene $\% 20$ TFM.pdfH.pdf

Morales, L., \& Goiriz, N. (2020). Riesgo ergonómico y estrés laboral de fisioterapeutas del Hospital de Clínicas, Facultad de Ciencias Médicas. Paraguay. Anales de la Facultad de Ciencias Médicas (Asunción), 53(2). https://doi.org/10.18004/anales/2020.053.02.79

Rodríguez, V., López, A. F., Moreno, G., Abecia, C., \& Seco, J. (2006). Efectos de la Vibroterapia sobre la actividad eléctrica del músculo fatigado. Fisioterapia, 28(6), 315322. https://doi.org/10.1016/S0211-5638(06)74066-4

Salgado-Guadarrama, J. (2015). Aplicacion del Metodo RULA (Rapid Upper Limb Assement) para determinar el riesgo ergonomico en enfermeras instrumentistas de un hospital de tercer nivel. https://doi.org/10.13140/RG.2.1.4617.7444

Torres, L., Camarillo, K., \& Orozco, H. (2013, October 1). "Análisis y diseño de un soporte ajustable de cadera y espalda aplicado a un dispositivo robótico para rehabilitación de extremidades inferiores”. XV Congreso Mexicano de Robótica 2013.

Ven, G. (2017). Bluetooth: que es? Para que sirve? Como usar Bluetooth? Problemas de conexión. Tecnologia+Informatica. https://www.tecnologia-informatica.com/ bluetooth/\#Que_es_Bluetooth? 
Wibelinger, L., Secchi, J., Francys, M., Miotto, G., Pasqualotti, A., \& Schneider, R. (2013). Fisioterapia convencional vs. wiiterapia: efeitos na força muscular de mulheres idosas com osteoartrite de joelho. Conscientiae Saúde, 12(1). https://doi. org/10.5585/ConsSaude.v12n1.3877 
